\title{
Astronomy and International Co-operation
}

$\mathrm{I}^{\mathrm{N}}$ his presidential address to the Royal Astronomical Society at its annual meeting on February 9, Prof. F. J. M. Stratton sketched the development of schemes of international co-operation in astronomy during the last hundred years. The first such scheme was that of the Berlin Academy for a chart and catalogue of stars down to the 10th magnitude, to be completed by a number of continental astronomers by 1828 ; it was actually not completed until 1858 . Along the same lines were the plan of the A.G. zone catalogues drawn up in 1869 , and later still the more ambitious photographic "Carte du Ciel" set on foot in Paris in 1887 and not yet completed. The founding of the "Centralstelle" for astronomical telegrams and the various activities of the Astronomische Gesellschaft kept the Germans for many years the chief organisers of joint astronomical schemes, but after the Permanent Commission of the Carte du Ciel had been established with its occasional gatherings of astronomers at Paris, the headquarters for international astronomy of position shifted to France.

In Paris were held conferences on fundamental stars and on co-operation in the work of preparing national ephemerides; there too were established the Bureau de l'Heure and the Bureau des Poids et Mesures. The United States became active in this sphere at the Washington Conference of October 1884, when the meridian passing through the centre of the transit instrument at the Observatory of Greenwich was adopted as a single prime meridian for all nations. From the United States, too, came the impetus which founded the International Solar Union; this body performed for solar and stellar physics the same function as that of the Permanent Commission of the Carte du Ciel for the older astronomy.
The War cut right across the older organisations, and in 1919 the International Astronomical Union was founded in an attempt to start once again the sadly crippled forces of co-operation. The new body set up more than thirty committees to deal not only with the work inherited from the earlier organisations but also with many branches of astronomy, such as double stars, which had remained unprovided for owing to the casual way in which the earlier schemes had come into being. Over the whole field of astronomical research the Union, without in any way interfering with individual liberty, has endeavoured to provide a common meeting ground for the discussion of problems and the preparation of schemes of mutual co-operation. Valuable reports from the various committees have been published, notably on standard wave-lengths, stellar photometry and stellar classification; these have been published in the volumes of transactions freely distributed to observatory libraries.

Grants in aid have been made by the Union for the publication of tables and observations, for printing volumes of the "Carte du Ciel", for the Bureau de l'Heure at Paris and the Bureau of the Variation of Latitude at Mizusawa, for computations in connexion with the recent opposition of Eros. (The Astronomer Royal gave an account of the progress of this work at the same meeting of the Royal Astronomical Society-a valuable illustration of the work of the Union.) In all, grants of more than $£ 14,000$ have been made by the Union to its committees. The present financial world crisis has not left the Union unscathed, but it is continuing "alive and responsive to new needs and changing conditions, a powerful support of astronomy in all its branches and a centre of co-operative good-will among the astronomers of the whole world".

\section{History and Management of the Hope Farm, Jamaica}

To the British Empire, the problem of milk production in the tropics is of paramount importance. It is a problem which at the present moment faces both the administrators and their agricultural advisors in each one of the British tropical dependencies and in India. The "History of the Hope Farm and Part 1 of the Jamaica Herd Book of Pure Bred Cattle" by H. H. Cousins, is an outstanding contribution to this subject $(\mathrm{Pp}$. vi+ $308+59+54$ plates. Kingston, Jamaica : Government Printing Office, 1933). This Jamaican estate, becoming derelict, passed in 1909 into the hands of the Government and represents a somewhat unusual incident in Government operations by which an officer was called upon to justify, as a commercial concern, the acquisition of land as public property, practically without capital and dependent upon the earnings of the enterprise for its development. The assets of the Farm now show a gain of nearly $£ 16,000$, or an annual increase averaging $£ 751$ from 1910 until 1931.

What will mostly appeal to livestock men in the tropics is the detail which has been put forward concerning the productivity of cows of many pure breeds and of their crosses. Many of the imported cows were of British breeds and came from Great Britain or North America. From India came the Nellore, Sahiwal and other Zebu cattle. The lifetime history of each cow is clearly set out. Several experiments in inbreeding were attempted, but the only one which appears to have had any measure of success involves the mixture of the Zebu with the Jersey. The excellent photographs, studied in conjunction with the records of the animals concerned, provide useful information.

An interesting point in the organisation of this farm, and one which may be commended to the attention of Colonial administrators, relates to its finances. It was recognised from the start that this enterprise should be operated on a separate account at the Treasury. The approval of the Secretary of State was obtained for this departure from the usual system of departmental finances, whereby expenditure was 'debited' and the revenue 'credited' to the general account without any direct connexion between the two. The method adopted for Hope Farm allows that freedom of decision which is essential for the proper conduct of a farm.

More important still is that where genetic experiments with cattle are concerned, the financial establishment of a farm should be along these lines, in order that there may be continuity in method over that period of years which is demanded by the nature of the investigation. Too often has a change in the 